\title{
Against Hostile Nature: The Roles of Magic and Science in Thailand's Cave Rescue
}

\author{
Kanya Wattanagun \\ Ph.D. Assistant Professor, Thai Studies Center, Faculty of Arts, \\ Chulalongkorn University, Bangkok, Thailand \\ Kanya.W@chula.ac.th
}

\begin{abstract}
The rescue mission at Tham Luang cave in Chiang Rai, Thailand, presents a scenario in which magical rituals and technical knowledge were marshaled against hostile natural conditions. While practical endeavors were made to mitigate the risks and impediments posed by malign weather and topographical features of the cave, myths and rituals were enacted to control unruly factors not subject to human manipulation. In this paper, I argue that: 1) Magical rituals at Tham Luang cave did not originate from the participants' confidence in the reality of supernatural beings but from their attempt to use alternative approaches to remedy a precarious situation when practical efforts and technical knowledge did not yield a desired outcome. 2) In this case, the participants regarded the reality of supernatural beings and their role in the rescue as a possibility rather than a self-evident truth.
\end{abstract}

\section{Keywords}

Thai cave - magic - ritual - science - spirit beliefs

\section{Introduction}

Scholars who study supernatural beliefs and practices in present-day Thailand note the proliferation of supernatural traditions in the modern environment. Their findings defy the age-old assumption that "supernatural beliefs are survivals from a naïve past and must decline as scientific thought ascends $[\ldots]$ " 
(Goldstein, Grider, and Thomas 2007, 61). In his examination of the role of sorcery in the social life of Thai urbanites, Louis Golomb (1993, 33-37) attributes the pervasive use of magic to volatile interpersonal relations in the competitive and profit-oriented urban environment. Pattana Kitiarsa (2005, 485-87), studying spirit medium cults in capitalist Thailand, notes that consumerism, mass media and the mixture of local customs in an urban environment contribute to the emergence of diversified and hybrid spiritual practices. In his analysis of three spiritual cults that flourished during Thailand's economic boom, Peter A. Jackson (1999) delineates ways in which the country's socio-economic and political contexts of the 199os shaped the emerging cults. These studies all conclude that supernatural traditions are alive and well in modern-day Thailand where "outmoded" beliefs and practices were expected to die out due to the hastened pace of development.

A peculiar incident that occurred in June 2018 in Chiang Rai, Thailand, reaffirmed the viability of supernatural beliefs in contemporary Thai society as numerous studies, including the aforementioned, have noted (Johnson 2011; Rajah 2005; Taylor 2015). This incident revealed that the persistence of mystical traditions may be ascribed not only to the predicament of modernity with which Thais try to cope but also to the way in which they coordinate magical actions with practical endeavors. The incident involved collaboration between rituals and technical knowledge, which was aimed at accomplishing a daunting task. In my view, the incident presented a scenario in which magic and science were utilized as different means of addressing a crisis. Rather than being competing theories regarding the nature of reality that refute one another, science and magic at Tham Luang cave represented distinct mental and behavioral schemes that participants combined and marshaled against the hostile environment. Participants performed rituals to support and reinforce practical actions, which were impeded by unruly natural forces. These individuals employed supernatural traditions as alternative approaches, rather than definite solutions, to the crisis they faced.

This paper discusses the Tham Luang cave rescue and the roles of magic and science - more precisely, myth/ritual and technical knowledge/practical action - in the collective effort to rescue thirteen individuals from a hostile natural environment. On June 23, 2018, a junior soccer team consisting of twelve boys, aged eleven to sixteen, and a 25-year-old coach disappeared into Tham Luang Nang Norn Cave (the majestic cave of the reclining lady) - a labyrinthine cave complex in the area of Tham Luang Khun Nam Nang Norn Forest Park, Chiang Rai. The soccer team became trapped inside the cave after heavy rain flooded the cave entrance. As the news of this mishap spread, local authorities, the Thai military and experts and volunteers from within the 
country and beyond joined forces to carry out a rescue mission. In addition to their meticulous rescue plans and advanced supporting devices, participants sought help from myths and rituals when practical endeavors were aborted due to unruly natural factors and unexpected events. On the basis of this rescue operation, I advance two arguments in this paper. 1) Ritual participants at Tham Luang cave enacted myths and rituals to mitigate the risks posed by volatile natural conditions and other impeding factors that disrupted practical endeavors. Spirits and deities invoked in the rituals personified those unruly factors, which participants knew would determine the outcome of the mission yet lay beyond their control. 2) Magical rituals performed at Tham Luang cave did not originate from the participants' confidence in the reality of supernatural beings but from their attempts to address a precarious situation via alternative approaches after practical endeavors failed to yield the desired outcome. In this case, participants regarded the reality of supernatural beings and their role in the rescue as a possibility rather than a self-evident truth.

The account of the rescue mission given below is my synthesis of domestic and international media content. Reactions of those involved in the operation are gleaned from interviews and news reports produced by the Thai and foreign media. I have translated from Thai to English the quoted content of domestic reports. I acknowledge that the objects of my analysis are secondary data, since they are representations of the cave rescue brought to the public by the mass media. Therefore, I consulted as many sources as possible in order to ascertain the integrity of the materials under scrutiny.

\section{Science and Magic against Hostile Nature}

\subsection{The Rescue of the Wild Boars}

On June 23, 2018, the Wild Boars, a junior soccer team consisting of twelve players and their young coach, spent Saturday afternoon after a practice session inside Tham Luang Nang Norn Cave (the majestic cave of the reclining lady) - a cave complex that winds through the Doi Nang Norn mountain range in the Mae Sai district of Chiang Rai province. The mountain, when viewed from east to west, looks like a woman lying on her back with her face turned skywards.

The cave, hereafter referred to as Tham Luang, runs through the lower ridge of the range, which is located between two higher mountains. Surrounded by several waterfalls and subterranean watercourses, Tham Luang is usually flooded during the monsoon season, which generally lasts from July to November. 
In a nationwide press conference broadcast on July 18, 2018, Ekkapol Chanthawong, the assistant coach of the Wild Boars, revealed that a few hours after entering the cave, the group noticed the steadily rising water level. The team decided to halt its exploration only to find that the exit route was flooded. The players and their coach retreated into the cave until they reached a dry slope called Nern Nom Sao (the hill of the maiden's breasts), where they were stranded in total darkness for eighteen days.

The first rescue team arrived on the scene at 10:0o p.m., on the same day the team became trapped. However, the local rescue team was unable to search inside the flooded cave. The heavy monsoon and the topographical features of Tham Luang were major hindrances to the local rescue workers who were inexperienced in cave diving. Another threat came from overflowing subterranean water, which raised the water level inside the cave to a dangerous height. The local authority then sought expert assistance. In response to a request made by the chief commander of the rescue mission, Thai Navy SEAL s sent over twenty officers to the operation base in the early morning of June 25 . They started their search upon arrival at the cave. However, by the morning of June 26 , the water level had nearly reached the cave ceiling. The search was thus suspended while the rescue team installed water pumps and pipelines in an attempt to drain the submerged tunnel. This served only to stabilize the water level without reducing it. In parallel with the operation being carried out inside the cave, some rescue units hiked to the mountaintop to locate shafts and holes leading to the heart of the cave.

As soon as the water receded, Navy SEALs and international cave diving experts continued their search inside the flooded cave. On the night of July 2 , two professional cave divers - John Volanthen and Richard Stanton - finally found the Wild Boars. The junior footballers and their coach were safe and sound after ten days of being confined within a pitch-dark tunnel without food. However, the rescue team now faced another critical task, which entailed transporting the Wild Boars out of the flooded cave. Nern Nom Sao, where the children and their coach were found, is positioned 4.3 kilometers from the cave entrance. To get out of the cave, the Wild Boar players would have to dive for most of the journey since the passage was almost entirely submerged. The team's physical condition and inexperience in cave diving were among the issues of concern for the rescue team (Thairath Online 2018). Given the challenges associated with the journey to the exit, the rescue team took elaborate security measures. The SEAL $s$ team laid guide ropes all the way from the cave entrance to Nern Nom Sao. Rescue workers placed oxygen tanks at three locations along the route. Air was pumped into the cave via newly laid pipelines to boost the oxygen level inside the cave. Finally, after the water level had 
lowered to a point that was more manageable, the rescue plan was executed. The twelve Wild Boar players and their coach safely left the cave in three rescue operations carried out from July 8 to July 10.

\subsection{The Mystical Approaches to the Rescue}

While the rescue workers and specialists carried out practical actions and applied technical knowledge, the families of the Wild Boar players employed myths and rituals when the non-mystical measures did not yield the desired outcome. On the morning of June 25, parents and relatives of the Wild Boars held an expiatory ritual whereby they addressed the female spirit whom they believe rules over the mountain and the cave. They attributed the failure to locate the Wild Boars and the malign natural conditions to Jaomae Nang Norn (the divine mother Nang Norn), the ghost of a mythical princess who died from overwhelming grief. There are numerous versions of her story in circulation, yet each version invariably tells of an ill-fated love between a princess and a stable boy. The lovers decided to elope because the princess's father disapproved of their relationship. They took refuge in Tham Luang, away from human settlement. One day, the stable boy went out in search of food, leaving the pregnant princess alone inside the cave. The stable boy was seized and killed by the king's men who had tracked down the couple. Oblivious to her lover's death, the princess thought he had deserted her. Some versions have it that the princess simply lay down and died. Others claim that she took her own life using a sharp hairpin. Later, her reclining body became the Nang Norn mountain range, which, from afar, looks like a pregnant woman lying on her back.

On June 26 , the SEAL s reached an elevated sandbank inside the cave - one of a few spots where the Wild Boars were able to remain safe inside the flooded tunnel - yet they found no trace of the team. Upon learning of this failure, the distressed parents and relatives held a soul-calling ritual to help their children find their way back home. Normally, the soul-calling ritual (known as phithi hong khwan among the northern Thai) is performed to remedy soul loss triggered by a trauma or chronic illness. (Anuman Rajadhon 2009, 208). In the context of the Tham Luang rescue, I suggest that the expiatory ritual on June 25 and the subsequent soul-calling ritual were held out of a strong sense of uncertainty. Distressed parents and relatives witnessed the failure of expert-led and fully equipped rescue workers to locate the missing soccer team after two days of intense search. As practical actions had not yielded the desired outcome, worried families resorted to ritual in order to remedy the situation. Namhom Bunpium, the mother of a Wild Boar player, revealed to the media that the expiatory ritual performed at Tham Luang on June 25 was intended to "entreat 
sacred beings ( sing saksit) to uncover the path and let the children out" (PPTV News 2018). Tham Kanthawong, the aunt of the young coach, shared a similar view when she surmised that the Wild Boars had offended the divine mother of Nang Norn mountain when they had trespassed on her territory. As such, she presented offerings to the goddess to beg forgiveness on behalf of her nephew (Channel 7 News 2018).

By June 27, it was clear to all parties involved that the Wild Boar players' safety was dependent upon the water level within the cave. While water pumps were being operated around the clock to drain the cave, families took part in another supplication ritual; this one involving a sequence of elaborate ceremonies. Unlike the previous expiatory ritual in which laymen simply laid out their offerings on the ground, a Brahmin priest led the ritual held on June 27. This second ritual took place at the shrine of Jaomae Nang Norn near the cave entrance. Jirasit Ploydam - a Brahmin from Phatthalung province in the south of Thailand - showed up at the cave and volunteered magical assistance. In addition to basic offerings, such as betel nut and banana leaf worshipping trays, Jirasit presented thirteen human dolls to the princess on behalf of the supplicants. The effigies were substitutes offered to the goddess in exchange for the thirteen Wild Boars. Central to the ritual was a collective oath taking in which parents promised to have their children ordained for nine days if they were returned safely. The food the novices received from their daily alms round was to be offered to the princess together with religious merit they earned from temporarily living the ascetic life. Following the lead of the Brahmin, the worshippers reproduced the vow verbatim. ${ }^{1}$

In the first few days of the mission, when the morale of families and workers was still high, the magical rituals performed at Tham Luang were less elaborate. The soul calling ritual held on June 26 featured a performance of traditional drums and cymbals, which produced loud and cheerful music intended to summon the souls of the missing Wild Boar players. ${ }^{2}$ In the preceding expiatory ritual performed on June 25 , participants simply presented offerings consisting of food, candles and banana leaf worshipping trays (pan baisri) to the offended Jaomae Nang Norn. Then, per the ceremony held on June 27, Jaomae Nang Norn was no longer considered a whimsical spirit easily appeased by food and other mundane offerings. She was imagined to be wanting more, which prompted worshippers to promise her religious merit instead of worldly materials. Toward the end of the mission, after the situation had deteriorated

1 A video clip covering the oath-taking ceremony is available online at the Khaosod (2018a) webpage, accessible via https://www.khaosod.co.th/breaking news/news_1268124. 
and all practical endeavors aimed at averting the adverse natural conditions had failed, princess Nang Norn's role in the rescue mission became more prominent. Worshippers embellished her tragic love story to rationalize the malign natural conditions that impeded the search. In the story they told, she was portrayed as a restless ghost harboring an unfulfilled desire, which would only be satisfied when the reincarnation of her past-life lover, Khruba Bunchum, visited the cave.

Khruba Bunchum and his disciples showed up at the operation base during the evening of June 29, after another rainstorm had hit Tham Luang. His lay and ordained adherents refer to the monk as khruba (revered teacher), an honorific title in the northern Thai Buddhist tradition reserved for senior monks who are highly revered (Ashley 2012, 71; Cohen 2001, 228). In 1966, Khruba Bunchum was born in Chiang San, a rural district of Chiang Rai. He was ordained as a novice at the age of eleven and then as a monk in 1986 (Jirattikorn 2016, 383). Upon his arrival at the operation base, Khruba Bunchum performed an apotropaic ritual to ward off any hindrances that had hampered the mission since its inception. Reporters who observed the ritual in situ mentioned a white cock and a white rabbit, which were set free in front of the cave. In addition to living animals, an offering bowl containing flowers, rice, fruit and an assortment of delicacies was presented to the princess. Then Khruba Bunchum and his disciples chanted Buddhist sutras before they performed a water pouring ceremony. ${ }^{3}$ Observers also noted sounds being produced by conches and bells, which could be heard throughout the ritual. Upon leaving, Khruba Boonchum delivered a prophecy regarding the thirteen individuals trapped inside the cave; he stated, "There's nothing to worry about. Everything is all right. In a day or two, they will be found. All are still alive" (Thairath 2018).

On June 30, the downpour that had jeopardized the operation ceased. This improvement of the situation, as well as a peculiar story shared by Facebook user Nattanuch Prasertong, elicited widespread remarks on the efficacy of Khruba Bunchum's ritual. On June 27, Nattanuch took to Facebook to relate an eerie dream she had had. In her dream, a woman demanded that Nattanuch summon "Bunchum", or else she would detain all the Wild Boar players and

2 The footage showing the complete ritual is published by MGR Online (2018) at the following URL: https://mgronline.com/onlinesection/detail/96100ooo63389.

3 In Thai Buddhist tradition, water pouring after a religious activity serves as a means of transferring merit to the third party who is believed to be blessed by the transferred merit, even though the person has not performed the religious act him- or herself (Keyes 1973, 96; Wells 1960, 118). 
their coach. The mysterious woman claimed that she had been waiting for three hundred years for Bunchum, whom Nattanuch believed was the Buddhist monk Khruba Bunchum, to set her free. The woman claimed that no one else could save her because of the karmic bond she and Bunchum shared.

The post did not catch the public's attention until June 30, when Khruba Bunchum conducted another ritual in the cave grounds. Media reports and personal remarks discussing the immediate efficacy of the ritual sprouted shortly after the event. A rescue worker, for instance, noted during a talk show that the dark clouds that had hung low above Tham Luang had dissipated as the ritual progressed (GMM Grammy PLC. 2018). Referring to Nattanuch's Facebook post, the Thai public began discussing the possibility that the monk was actually the stable boy reincarnate. For those who subscribed to Nattanuch's story, the post explained why Jaomae Nang Norn, having previously shunned all pacification, relented after Khruba Bunchum's intervention. Once the monk's prophecy came true, this notion gained additional support. On the night of July 2 , the thirteen members of the Wild Boars soccer team were found alive inside the cave.

Via her Facebook post, Nattanuch suggested that the malign natural conditions and failed practical actions were the work of Jaomae Nang Norn, whom Nattanuch regarded as a conscious agent deliberately causing mishaps so that she might achieve a desired end. The post also rationalized the inefficacy of the rituals prior to Khruba Bunchum's intervention. Since the misfortune that befell the Wild Boars was part of the princess's scheme to summon her savior, practical and magical actions that did not lead to this end failed to ameliorate the situation. Nattanuch's account of Princess Nang Norn's demand renders the hardship and failures that surrounded the mission intelligible to those who subscribe to her story. The post explains the intent and desire of a malicious supernatural being who was believed to wield power over the mission.

Magical rituals continued after the Wild Boars were found. Families and relatives, acutely aware of the adverse natural conditions that impeded their children's journey to the cave exit, took part in another ritual led by Khruba Bunchum. Although the weather was fair from June 29 to July 6, another monsoon was forecast to hit Chiang Rai beginning July 7 (Khaosod 2018b). Given the precarious nature of the impending weather, Khruba Bunchum conducted his third ritual in the cave grounds on July 4. This ritual, according to Kiang Khamlue whose son was trapped inside the flooded cave, was performed to convey loving-kindness and blessings to the grandfather Naga (phopu phayanak) - the deity who controls rain and subterranean water at Tham Luang (тNAMCOT 2018). In Thai Buddhism, compassion and good wishes are 
believed to contain positive power that can turn an enemy into an ally. As such, one method by which to pacify a spiteful being involves expressing compassion toward the being and wishing in earnest for its well-being (Harvey 199o, 209). The final ritual led by Khruba Bunchum expressed a similar sentiment that characterized the preceding rituals. The natural forces that impeded the rescue were construed as hostile supernatural agents that had to be pacified in order to ensure the success of the mission.

\section{$3 \quad$ Making Sense of the Rituals at Tham Luang Cave}

А ввС documentary entitled Sorry Nang Norn: Appeasing a Thai Cave Spirit covers the elaborate ceremony held on July 16 - a week after the thirteen Wild Boars left the cave. ${ }^{4}$ The documentary suggests that the locals who partook in the rescue resorted to magical rituals because they believed in the reality of supernatural agents. The description of the ceremony, provided in the documentary, implies that supernatural belief forms the basis of magical ritual:

The Thai cave boys are out... and some believe it's thanks to Nang Norn. She's the spirit of a mythical princess who died and became a mountain and has lived for centuries in Tham Luang cave. Many prayed to her when the boys first went missing. [...] Many think the boys' intrusion offended Nang Norn and local deities. So, they held an elaborate ceremony... and laid out offerings to say sorry. (WONG 2018, N.P.)

This interpretation of the ceremony elicited diverse reactions from various audiences, including Internet users who left their comments on the YouTube page where the documentary was being hosted. Some, adopting a rationalist viewpoint, expressed disapproval of the ignorant folk who failed to see that the Wild Boars were saved by the concerted efforts of their fellow humans, rather than by some obscure supernatural beings. Others, holding a cultural relativist view, argue that the ritual was sensible within a Thai worldview that regards natural entities with gratitude and respect. The ceremony mirrors a cultural attitude that recognizes and appreciates the role of nature in human wellbeing. Others, construing the ceremony as a form of nature worship, observe that

4 Khaosod (2018c) published the unedited footage depicting the entire ritual. The video is available online at https://www.khaosod.co.th/breaking-news/news_1346761. 
the practice was not peculiar since it can be found among a wide range of cultures.

These comments presuppose a causal relation between supernatural belief and magical ritual. Despite the diverse stances they adopt, commenters invariably hold that since worshippers believe in the reality of Princess Nang Norn and other deities, they carried out rituals to supplicate these spiritual beings. Stemming from this line of thought are the various conjectures viewers of the document made regarding the reasons why believers retain and practice these mystical ideas of reality. Some attribute them to the believers' ignorance and others relate them to the believers' cultural lenses that influence their perceptions of and reactions to the incident at Tham Luang. Divergent public opinions ultimately share in a single assumption: Those who adopted mystical approaches to the rescue mission must believe in the reality of supernatural agents; otherwise, they would not have sought help from magical rituals.

I argue that the magical rituals carried out during and after the rescue mission can be interpreted from a different perspective - one that revisits the prevailing paradigm of belief as the basis of ritual (Sørensen 2005, 51; Staal 1996, 126). As indicated in the foregoing section, parents and relatives of the Wild Boars sought help via supernatural traditions after they witnessed the failure of practical actions. Seeing that technical knowledge and advanced supporting devices might be unable to save their children, anxious parents and relatives approached the situation via alternative means. In this context, rituals did not stem from a steadfast belief in the reality of the supernatural world but from the inclusive mindset that does not rule out any possibility. I contend that the proponents of supernatural approaches to the rescue mission did not believe in the existence of Princess Nang Norn, if believing implies a complete trust in the truth value of a proposition and the rejection of contrary truth claims (Bowie 2006, 20). Instead, failed practical endeavors and numerous hindrances surrounding and thus greatly affecting the mission compelled them to consider the possibility that some supernatural agents may have turned hostile against the rescue efforts. Therefore, pacifying these unknown beings could effectively improve the situation.

To elucidate the aforementioned argument, I discuss two attitudes held by the locals who opted to employ supernatural approaches to the rescue mission: 1) Some participants noted that the mission had been heavily impeded too many times, as if the impediments had been conjured by some conscious agents who intended to jeopardize the rescue. 2) Several other participants viewed the rituals as a complement to, rather than a substitute for, practical action. 
In a talk show about paranormal experiences at Tham Luang, Kampolsak Sasadee - a rescue worker - admitted that he found the story of Princess Nang Norn and the grudge she harbors against humans who trespass on her territory convincing because, as he stated, "All rescue units faced all kinds of obstacles but none of us brought them up. We were on duty. Talking about them would have spoiled the team's morale" (GMM Grammy PLC. 2018). Kamei Promthep, whose grandson went missing inside the cave, described her puzzlement and foreboding triggered by the failure to locate the boys despite the immense effort of all rescue units; she said, "I was wondering, 'Where could they be?' A lot of people came and helped, so why couldn't we find the boys? I remained at the cave and cried" (Channel News Asia 2018). Given her participation in most of the rituals that took place in the cave grounds from June 25 onward, Kamei seemed to entertain the idea, articulated by Kampolsak, that some supernatural agents may have been the sources of the grave and frequent hindrances. Both individuals considered mystical theory but it was not their immediate response; they only considered it after noting the futility of practical actions and the unexpected events that had thwarted the mission. In addition, we cannot ignore the fact that the first ritual was performed on June 25, the third day of the mission, after the families of the missing children had acknowledged that the rescue would be hard-won because too many unfavorable, unruly factors were involved. Mystical assessment of the crisis was not taken for granted; rather, it was considered only after it was clear to the distressed families that the primary approach to the problem - the non-mystical one - was inadequate.

It is also worth noting that the families, while opting for rituals, did not disregard practical actions. They accepted that meticulous rescue schemes were pivotal to the success of the mission, while mystical approaches were supplementary to the practical endeavors being carried out. From their reactions to the crisis, one can infer that they construed magical rituals as a complement to, rather than a substitute for, practical actions. As such, magical rituals and practical endeavors are not antithetical approaches to a problem that contradict or refute one another. Rather, for many participants of magical rituals at Tham Luang, the ceremonies were held not in lieu of practical endeavors but to ensure the smooth execution of the rescue plan and the best outcome of the mission.

The idea that magical rituals complement and reinforce practical actions is evident in the participants' attitudes toward magic vis-à-vis science in the rescue mission. Tham Kanthawong, an individual who presented offerings to Princess Nang Norn, revealed to the media that her morale increased as she saw how state agencies had joined forces with local and international rescue 
teams in the mission (Amarin TV 2018a). However, in another interview conducted on the same day by a different news agency, Tham remarked that the Wild Boars might have offended the divine mother Nang Norn, which is why she thought an expiatory ritual might be helpful (Channel 7 News 2018). In yet another interview conducted on-site on June 27, Tham expressed her optimism as she witnessed the deliberation and devotion of all the rescue units. Nonetheless, she also expressed her appreciation for spirit mediums and their magical assistance. Tham elaborated that rituals were alternative measures to ameliorate the situation and she was willing to employ any means that might help (Amarin TV 2018b). The distressed but hopeful aunt seemed to recognize that the practical endeavors made by all involved parties were the key to the mission's success, while rituals were feasible options that she believed could assist in the operation in the event that mystical beings intended to disrupt the rescue.

Other ritual participants explained to the media that they supplicated the deities at Tham Luang for the unimpeded and successful operation of the rescue plan. For them, practical actions were still of primary importance while rituals were held to ease and enhance the performance of the rescue teams. Venerable Maha Aphiwat Kantasilo, who led an expiatory ritual performed in the cave grounds on June 27, revealed to a national newspaper that the ritual was aimed at "making an apology and transferring merit to Jaomae Nang Norn and other deities at Tham Luang, so that they uncover the path and the rescue teams promptly find the Wild Boars" (Matichon 2018; emphasis added). The venerable seems to recognize that ultimately, the rescue teams carried out the search hence only via their endeavors could the Wild Boars be retrieved. Nonetheless, he held the ritual hoping that the appeased deities would ease the search. In this perceived relationship between magical ritual and practical action, the former assists the latter rather than substituting it. The mother of one of the missing children expressed a similar view of magic vis-à-vis science in the rescue mission. She construed rituals as an alternative approach to the crisis worth experimenting with, not as the principal solution taken in lieu of practical effort made by the rescue teams. To the media, she stated: "I will do everything. Belief is all in one's mind, but I will try all means to bring the children back" (Channel 3 News 2018). For the woman, ritual is an issue of personal belief that varies from one person to another but it was an alternative approach to the crisis that she did not dismiss. The woman also expressed her faith in practical endeavors, stating, "I also trust the rescue team. I believe they will reach the boys on time" (Channel 3 News 2018). Like other ritual participants whom I mentioned earlier, this woman acknowledged the paramount 
role of practical actions in the rescue, yet she also referred to rituals as an alternative approach to the crisis that could be put to the test.

Myths and rituals at Tham Luang cave served as alternative problem-solving strategies adopted by a group of troubled humans. Parents and relatives of the missing Wild Boars drew on the myth of Princess Nang Norn to rationalize the disruptive occurrences that hinder practical endeavors. They carried out rituals, devised and performed according to the associated myths, to ward off these unruly impediments. I suggest that belief was not the basis of rituals in this case because the participants regarded the reality of supernatural agents and their intervention in the rescue as a possibility, not a given. In addition, the participants drew on the rituals as feasible alternatives rather than as absolute solutions to the crisis. I discuss the ramifications of this argument in the following section.

\section{4}

\section{Conceptualizing Alternative Ways of Believing}

Anthropological enterprise in the twenty-first century has witnessed the so-called ontological turn - a methodological and theoretical approach that "poses ontological questions to solve epistemological problems" (Holbraad and Pedersen 2017, 5). A concern that has occupied anthropologists since the zenith of Boasian relativism is the influence of the ethnographer's worldview, which is socially and culturally derived, on his or her analysis of other cultures. The ontological turn approaches this problem from a different angle. It does not discuss how people from diverse cultural backgrounds see the same thing in different lights. Instead, it explores multiple possibilities of what the object, the practice or the phenomenon under scrutiny is and can be. The ontological turn draws the ethnographer's attention not to differing socio-cultural contexts that result in multiple ways of seeing the world but to the ingrained ontological assumptions that prevent a member of a specific culture from conceptualizing the observed custom, practice or phenomenon in other ways. The ontological turn differs from cultural relativism in that it encourages ethnographers to reflect on their understanding of what the object under scrutiny is and consider alternative ways to conceptualize it, as Holbraad and Pedersen explain:

Relativists tend to relativize by pointing out the ways in which forms of knowledge, truth or morality are contingent on differing social, cultural or historical circumstances. The ontological turn takes this to its logical 
extreme by questioning (note: this is not the same as denying) the universal validity of everything, including such notions as knowledge, truth, morality, society, culture and history. $(2017,13)$

I propound that the roles of magic and science at Tham Luang offer an alternative way of conceptualizing believing - a mental state that has been conceived as a commitment to an idea or a proposition, which the believing individual regards as true. Belief is a Western concept grounded in the religious and philosophical traditions of the society of its origin. Fiona Bowie notes the changing meaning of the term and its varying usage in different periods of British society. In old English, "to believe" meant "to hold dear". When used in the context of Judeo-Christian monotheism, belief in God denotes the loyalty to one true God. By the end of the seventeenth century, upon the rise of scientific rationalism, belief came to refer to "a choice between possible explanations or propositions" (Bowie 2006, 20). Therefore, the claim "I believe in God" denotes the speaker's confidence in the reality of God, which further implies his or her rejection of any views that contradict the held belief. In varying contexts, believing has been invariably conceived as: 1) a commitment to a specific idea or proposition, which one deems to be true, and 2) a dismissal of propositions that are in opposition to what one believes.

In the preceding section I posit that ritual participants at Tham Luang did not "believe" in Princess Nang Norn or any other deities that were invoked via the rituals carried out during the mission. The participants seemed to accept the reality of these supernatural agents as a possibility rather than a self-evident truth. I infer this attitude from the circumstance that led to the enactment of the rituals and the reactions of some ritual participants as covered by the media. Parents and relatives of the missing soccer team conducted the first ritual only after a long and vigorous search, which was constantly interrupted by adverse natural conditions, failed to yield satisfactory results. In my view, such employment of rituals after the failure of practical actions suggests that parents and relatives seriously considered the supernatural cause of the incident only after they appreciated the futility of non-mystical approaches to the problem. In addition, ritual participants whose reactions to the incident were described in the foregoing section acknowledged that practical actions and technical knowledge were pivotal to the success of the mission. Nonetheless, they sought to propitiate Princess Nang Norn and other deities, hoping that the rituals would smooth over and reinforce the implementation of the rescue plan. They did not regard ritual as the one true solution to the problem, nor did they express absolute confidence in the efficacy of mystical approaches. Based on this role of magical 
rituals, which anxious parents and relatives carried out to support practical actions, I propound that ritual participants accepted the reality of supernatural agents and their roles in the Tham Luang incident as a possibility rather than a given.

My reading of the magical rituals at Tham Luang reproduces Malinowski's psycho-functionalist theory of magic. Inquiring into the roles of magic and science in the life of the native Trobrianders, Bronislaw Malinowski construed magic as a means by which to reduce anxiety in an uncontrollable situation. The Trobrianders were well aware that all tasks require physical effort and technical knowledge, yet they put magic to use when the tasks at hand were deemed liable to uncontrollable external factors (Malinowski 1948, 12). Drawing on Malinowski's concept of magic, I have described how unruly natural factors that jeopardized practical actions compelled parents and relatives of the missing individuals to seek help from rituals. However, I delineate the interplay among the hostile and uncontrollable natural factors, anxiety and magical rituals to emphasize that worried parents and relatives did not immediately leap to supernatural theory in order to make sense of the incident. The situation deteriorated despite the vigorous and meticulously planned practical effort; therefore, the families of the missing soccer team reassessed the situation and sought alternative means to address it. As such, the ritual participants discussed here are appreciably different from primitives who, as described by Lévy-Bruhl, indiscriminately attribute all objects and entities of the natural world to "an occult and invisible power" (Lévy-Bruhl 1923, 36). In the case of the ritual participants at Tham Luang, naturalist and mystical orientations to the situation seem to relate to one another in a different way. Concerned families never glossed over or dismissed the importance of practical actions and technical knowledge, and rituals were conducted as an alternative approach that participants considered feasible and worth trying.

If believing denotes a confidence in the truth value of an idea or a proposition, it leaves no room for hesitation and uncertainty. Given that the term presupposes a person's faith in the veracity of the belief that he or she holds, it poorly reflects a mental attitude in which a proposition is taken as likely or possible rather than apparently true. Apropos the manner in which ritual participants assigned a secondary role to supernatural approaches vis-à-vis the pivotal practical actions, I suggest that spirit worshippers at Tham Luang considered the reality of supernatural agents and their intervention in the mission as a possibility rather than a self-evident truth. Referring to this attitude as a "belief" is inadequate and misleading since the term is entrenched in a specific conceptualization of possible relationships between humans and the supernatural world. Why do we have only "belief" and "disbelief" 
to describe diverse views humans hold regarding the reality of incorporeal beings? Can there be other attitudes that lie between the two extremes of the spectrum? Can we do away with the belief-disbelief dichotomy and develop conceptual alternatives that cogently reflect diverse ways in which people hold and practice their ideas of the supernatural world? (Wattanagun 2016, 251) I raise these questions to demonstrate that "belief", as a concept, resonates with ontological assumptions that preempt alternative ways of thinking and talking about varying conceptions of supernatural entities and their ontological status. The ontological turn urges ethnographers to cast doubt on their ideas of what the object under scrutiny is. Adopting this approach, I suggest that the interactions between worshippers and the deities of Tham Luang may be the manifestations of a distinct attitude regarding the reality of supernatural agents that is not equivalent to belief, and recognition of this discrepancy is fundamental to an adequate assessment of this attitude and its expressions.

\section{5}

\section{Conclusion}

Many of the activities that occurred in the cave grounds during the rescue mission may confound international observers. The rescue brought together professional cave divers and ritual masters in a concerted attempt to overcome a hostile natural environment. For some, this collaboration may indicate a persisting belief in the supernatural world among the locals. However, I posit that "belief" and "believing" poorly convey the attitudes of ritual participants, as those who carried out rituals in an effort to help the Wild Boars escape the tunnel did not take the reality of supernatural agents and the roles of these beings in the mission as an indisputable given. Rituals in this context served as alternative approaches to a critical situation that did not improve despite vigorous practical effort. Viewed in this light, it becomes clear that ritual participants at Tham Luang were not simply bearers of supernatural beliefs. Rather, they harbored an inclusive mindset that appreciates the operation of the mechanistic world but does not dismiss its mystical aspects.

\section{References}

Amarin TV. 2018a. "A Relative Denies: The Coach did not take the Boys to the Cave for a Soccer Practice. Offerings were Laid Out to Appease Deities - the Seals Saw 
Light of Hope." Banging the News Desk, June 25, 2018. https://www.youtube.com/ watch?v=qCPmteTGnS4. (In Thai).

Amarin TV. 2018b. "A Private Talk about the Rescue of the Thirteen Wild Boars: Dark, Cold Tunnel is not a Reason to Give Up." Banging the News Desk, June 27, 2018. https://www.youtube.com/watch?v=h-2B-4eWuY4. (In Thai).

Anuman Rajadhon. 20o9. Essays on Thai Folklore. Bangkok: Thai Studies Institute.

Ashley, Sean. 2012. "Charisma in the Margins of the State: Dara'ang Buddhism and the 'Khruba' Holy Men of Northern Thailand." Anthropologica 54, no. 1: 71-82.

Bowie, Fiona. 2006. "Anthropology of Religion." In The Blackwell Companion to the Study of Religion, edited by Robert Segal, 3-24. Cornwall: Blackwell Publishing.

Channel 3 News. 2018. "Parents Believe Their Kids will Survive, the Coach Will Take Care of the Boys. The Team Visited the Cave Several Times." Morning Stories, June 25, 2018. https://www.youtube.com/watch?v=tE83VdsZN7I. (In Thai).

Channel 7 News. 2018. "The Footballers' Families Waiting outside Tham Luang Khun Nam Nang Norn Cave Hold a Supplication Ritual." Hot Issues at Channel 7, June 25, 2018. http://www.mediastudio.co.th/2018/06/25/298444/. (In Thai).

Channel News Asia. 2018. Tham Luang Cave Rescue: Against the Elements, August 13, 2018. https://www.youtube.com/watch?v=x_kiXouUDNI.

Cohen, Paul. 2001. "Buddhism Unshackled: The Yuan 'Holy Man' Tradition and the Nation State in the Tai world." Journal of Southeast Asian Studies 32, no. 2: 227-47. https://doi.org/10.1017/Soo2246340100o11X.

GMM Grammy PLC. 2018. "Stories from Tham Luang Cave, Told by Rescue Workers." Laying Bare the Secret, July 11, 2018. https://www.youtube.com/watch?v=74YJi_ fmLx8 (In Thai).

Goldstein, Diane, Sylvia Grider, and Jeannie Thomas. 2007. Haunting Experiences: Ghost in Contemporary Folklore. Logan: Utah State University Press.

Golomb, Louis. 1993. "The Relativity of Magical Malevolence in Urban Thailand." In Understanding Witchcraft and Sorcery in Southeast Asia, edited by C.W. Watson and Roy Ellen, 27-45. Honolulu: University of Hawaii Press.

Harvey, Peter. 1990. An Introduction to Buddhism: Teaching, History, and Practices. Cambridge: Cambridge University Press.

Holbraad, Martin, and Morten Axel Pedersen. 2017. The Ontological Turn: An Anthropological Exposition. Cambridge: Cambridge University Press.

Jackson, Peter. 1999. "Royal Spirits, Chinese Gods, and Magic Monks: Thailand's BoomTime Religions of Prosperity." Southeast Asia Research 7, no. 3: 245-320. https://doi. org/10.1177/o967828X9900700302.

Jirattikorn, Amporn. 2016. "Buddhist Holy Man Khruba Bunchum: The Shift in a Millenarian Movement at the Thailand-Myanmar Border." Sojourn 31, no.2: 377-412. DOI: 10.1355/sj31-2a. 
Johnson, Andrew. 2011. "Re-Centering the City: Spirits, Local Wisdom, and Urban Design at the Three Kings Monument of Chiang Mai." Journal of Southeast Asian Studies 42, no.3: 511-31. https://doi.org/10.1017/Soo224634110oo385.

Keyes, Charles. 1973. "The Power of Merit." In Visakha Puja B.E. 2516, 95-102. Bangkok: The Buddhist Association of Thailand.

Khaosod. 2018a. "Heavy Rain, Sullen Sky! Families Invite Monks and Prepare Dolls for Another Ritual at the Cave Entrance." June 27, 2018. https://www. Khaosod.co.th/ breaking news/news_1268124(In Thai).

Khaosod. 2018b. "More Troubles await the Rescue Mission: Another Monsoon is Forecast to Hit Chiang Rai from 7-9 July." July 5, 2018. https://www.khaosod.co.th/ breaking-news/news_1303597 (In Thai).

Khaosod. 2018c. "A Lanna Ritual was Performed to Seal the Cave, Apologize to the Divine Mother Nang Norn, and Send Sergeant Sam to Heaven.” 16 July, 2018. https:// www.khaosod.co.th/breaking-news/news_1346761. (In Thai).

Kitiarsa, Pattana. 2005. "Beyond Syncretism: Hybridization of Popular Religion in Contemporary Thailand." Journal of Southeast Asian Studies 36, no.3: 461-87. https:// doi.org/10.1017/Soo22463405000251.

Lévy-Bruhl, Lucien. 1923. Primitive Mentality. Translated by Lilian A. Clare. London: The Macmillan Company.

Malinowski, Bronislaw.1948. Magic, Science, and Religion and Other Essays. Glencoe: The Free Press.

Matichon. 2018. "A Ritual was Held to Appease Jaomae Nang Norn and Retrieve the Thirteen Wild Boars." June 27, 2018. https:/www.matichon.co.th/news-monitor/ news_1017149. (In Thai).

MGR Online. 2018. "Locals Hold A Soul Calling Ceremony at the Cave Entrance according to Lanna Belief." June 26, 2018. https://mgronline.com/onlinesection/ detail/96100ooo63389. (In Thai).

P PTV News. 2018. "Families Supplicate Deities, Praying for the Safety of the Footballers and their Coach." Hot Evening News, June 25, 2018. https://www.youtube.com/ watch?v=Jwhljw_zMBE. (In Thai).

Rajah, Ananda. 2005. "Political Assassination by Other Means: Public Protest, Sorcery, and Morality in Thailand." Journal of Southeast Asian Studies 36, no.1:111-29. https:// doi.org/10.1017/Soo22463405000056.

Sørensen, Jesper. 2005. "Rituals as Action and Symbolic Expression." In The Cultural Heritage of Medieval Rituals: Genre and Ritual, edited by Eyolf Ostrem, Mette Bruun, Nils Petersen and Jens Fleischer, 49-64. Copenhagen: University of Copenhagen.

Staal, Frits. 1996. Ritual and Mantras: Rules without Meaning. Delhi: Motilal Banarsidass Publishers.

Taylor, James. 2015. "Urban Buddhism in the Thai Postmetropolis." In Handbook of Religion and the Asian City: Aspiration and Urbanization in the Twenty-First 
Century, edited by Peter van der Veer, 219-33. Oakland: University of California Press.

Thairath. 2018. "The Ritual Explained: Why it has to be Khruba Bunchum who Releases the Thirteen Lives from Tham Luang Cave." June 29, 2018. https://www.thairath. co.th/content/1322503. (In Thai).

Thairath Online. 2018. "The Rescue of the Thirteen Wild Boars has Begun: Four were out on the First Day." July 9, 2018. https://www.thairath.co.th/content/1330455. (In Thai).

тNAмсот. 2018. "Venerable Bunchum Performs the Path Uncovering Ritual for the Third Time." All News, All Issues, July 4, 2018. https://www.youtube.com/ watch?v=mXEYUCSog9o. (In Thai).

Wattanagun, Kanya. 2016. "The Ravenous Spirit (Phii Pob) Belief Tradition in Contemporary Thailand: Pluralistic Practices versus Monolithic Representations." PhD diss., Indiana University.

Wells, Kenneth. 196o. Thai Buddhism: Its Rites and Activities. Bangkok: The Christian Bookstore.

Wong, Tessa. 2018. "Sorry Nang Norn: Appeasing a Thai Cave Spirit.” BBC News, July 17, 2018. https://www.youtube.com/watch?v=4_Q_b4MWp1o. 